\title{
Komodifikasi Anime sebagai Budaya Populer Pada Komunitas Anime One Piece Di Kota Medan
}

\author{
Muhammad Irfan Syukhori Lubis \\ Universitas Muhammadiyah Sumatera Utara
}

\begin{abstract}
The development of technology and communication currently building all these things can be easily access including culture. The process of social and cultural occurring in the information revolution has become a fascinating subjects of the principle of social science for a long time. Is related to the process is a process komodifkasi cultural values change to become a value exchange.Komodifikasi cultural change culture so as to be a popular culture is very interesting .Researchers took survey areas in the community one piece id .The kind of research taken qualitative researchers is descriptive. The research data collection are, interview process observation and, documentation. Based on the research done, the anime komodifikasi as popular culture is in one piece id field community has been very good.Besides, the reciprocal existence in of the communication and the culture that emerged in communities with anime develop a community one piece id be the space for their fans anime one piece in exchanging information and spreading the culture so that people can receive the cultural.
\end{abstract}

Key Word: Komodifikasi, Anime, Popular Culture

\begin{abstract}
Abstrak
Perkembangan teknologi dan komunikasi saat ini membuat semua hal dapat di akses dengan mudah termasuk budaya. Proses sosial budaya yang terjadi di era revolusi informasi sudah menjadi bahasan yang menarik dalam kaidah ilmu sosial sejak lama. Ini terkait dengan proses komodifkasi budaya yang merupakan proses perubahan nilai guna menjadi sebuah nilai tukar. Komodifikasi budaya yang merubah budaya sehingga menjadi sebuah budaya populer merupakan hal yang menarik. Peneliti mengambil lokasi penelitian di Komunitas One Piece ID Medan. Jenis penelitian yang diambil peneliti adalah deskriptif kualitatif. Tahap pengumpulan data penelitian yaitu melakukan proses wawancara, observasi serta dokumentasi, hasil pengataman. Berdasarkan hasil penelitian, proses Komodifikasi Anime Sebagai Budaya Populer yang ada di Komunitas One Piece ID Medan sudah berjalan sangat baik. Selain itu, adanya timbal balik dari arus komunikasi dan tren budaya yang timbul di masyarakat dengan adanya komunitas anime One Piece ID Medan yang menjadi wadah bagi para penggemar anime One Piece dalam bertukar informasi maupun menyebarkan budaya sehingga masyarakat dapat menerima adanya budaya tersebut.
\end{abstract}

Kata Kunci : Komodifikasi, Anime, Budaya Populer 
Latar Belakang Masalah

Perkembangan cepat teknologi

dan komunikasi di era sekarang membuat semua hal dapat di akses dengan mudah melalui teknologi. Proses sosial budaya yang terjadi di era revolusi informasi sudah menjadi bahasan yang menarik dalam kaidah ilmu sosial sejak lama. Proses komunikasi di era sekarang tidak hanya interaksi antar individu melainkan bisa melalui berbagai cara dengan kecanggihan teknologi yang memperluasnya.

Berbicara tentang komunikasi tidak lepas dari pembahasan kandungan yang ada dalam komunikasi tersebut. Termasuk komodifikasi tren budaya populer yang di ambil dari budaya luar menjadi budaya yang dipakai oleh masyarakat, mulai dari gaya komunikasi, gaya hidup, dan konsep diri. Serta juga perubahan nilai budaya yang ada akibat dari timbulnya budaya populer.

Budaya populer telah menjadi kebutuhan dalam hal pemenuhan gaya hidup serta konsep diri yang menjadi imitasi dalam diri seseorang untuk mengikuti gaya maupun konsep diri seseorang. Mengutip Rahayu (2016:22-23) pada umumnya, proses pengalihan atau perubahan budaya difasilitasi oleh adanya kontak komunikasi melalui Bahasa. Tanpa bahasa, proses pengalihan kebudayaan tidak akan terjadi.

Tidak bisa disangkal bahwasanya budaya populer Jepang yang tertuang dalam anime itu sangat menarik perhatian dan mencakup berbagai kalangan serta tersebar dengan cepat ke seluruh dunia. Animator-animator Jepang sangat memberikan kreativitas dan ide yang tertuang dalam anime yang mereka 
buat serta dengan kualitas yang sangat tinggi. Mereka membuat tokoh dalam cerita anime mereka dengan sangat menarik sehingga penonton sangat tertarik untuk menonton, mereka membuat karakter anime dengan detail tinggi sehingga sangat menarik di mata penonton. Selain menarik para animator juga membuat para penikmatnya menjadi senang akan adanya hiburan tersebut. Seiring berkembangnya teknologi yang mendukung berkembangnya penyebarluasan informasi dan transaksi media anime tersebut. Membuat kreator-kreator anime sangat mudah untuk menyebarluaskan anime ciptaannya serta mempermudah penggemar anime dalam mengakses informasi maupun medapatkan tontonan anime kesukaan nya. Komoditas anime ini sangat berkembang dengan semakin banyaknya tercipta komunitas serta ajang festival manga dan kontes cosplay.

Selain itu perkembangan kepopuleran anime di Indonesia ditandai dengan semakin banyaknya orang yang ingin belajar tentang Bahasa Jepang yang dipengaruhi oleh anime. Oleh karena itu budaya populer yang ada juga membuat perubahan besar yang terjadi dalam nilai sosial di masyarakat.

Menurut Subiakto dan Ida (2012:150) budaya populer merupakan seperangkat ide, perspektif, sikap, gambaran, dan fenomena lain, yang menurut konsensus umum berada dalam lingkaran mainstream (arus utama) dari budaya yang ada (given culture). Budaya populer mulai dikenal dalam konteks budaya Barat di awal pertengahan abad ke-20, ketika kemunculan budaya mainstream global yang begitu marak di abad ke- 
20 hingga 21. Budaya populer

menjadi hadir di mana-mana, dipengaruhi oleh kehadiran media massa. Budaya populer kini telah menjadi bagian dari kehidupan sehari-hari masyarakat di dunia.

Menurut Heryanto (2012:11)

budaya pop seringkali dipahami terutama sebagai barang hiburan dan barang dagangan untuk meraup laba, meski ada kasus budaya (pop atau lainnya) yang terang-terangan dirancang untuk membuahkan pernyataan politik, dan kemudian jadi terkenal, atau dicekal karena alasan politik.

Bungin (2006:101) budaya populer juga menjadi bagian dari budaya elit dalam masyarakat tertentu. Sejauh itu pula budaya populer dipertanyakan konsepnya konkret, serta pengaruhnya yang lebih dirasakan seperti umpamanya apa perbedaan antara modernisasi dan posmodernisasi. Begitu pula pertarungan antara kebudayaan tinggi dan kebudayaan pop. Dalam hal ini akibat adanya budaya populer hingga membentuk suatu tatanan dalam dunia populer berupa komunitas dan juga fan culture yang menunjang penyebarluasan informasi dan teknologi serta perkembangan budaya populer yang ada di masyarakat.

Menurut penganjur teori komoditas budaya, dibandingkan komunitas-komunitas yang terisolasi secara geografis dan social seperti si era-era tumbuhnya tatanan masyarakat tradisional awal, tatanan masyarakat modern memiliki elite yang mulai mengembangkan bentuk subversif dari budaya massa yang mampu memaksakan dan mengganggu budaya kehidupan sehari-hari. Bentuk baru ini berfungsi secara amat halus tetapi 
cara berpikir yang efektif, antara produk yang nilainya muncul menyababkan orang keliru dari pemuasan keinginan dan menafsirkan pengalaman mereka dan kebutuhan khusus manusia, yakni bertindak melawan kepentingan "nilai guna" (use value), dan produk mereka sendiri (Ibrahim dan yang nilainya didasarkan atas apa Akhmad, 2014:25-26). yang bisa ia berikan dalam Ibrahim dan Akhmad (2014) pertukaran, yakni "nilai tukar" mengatakan komodifikasi adalah (exchange value). Komoditas adalah proses transformasi barang dan jasa bentuk tertentu dari produk ketika yang semula dinilai karena nilai produksinya terutama gunanya (misalnya, nilai guna diorganisasikan melalui proses minuman untuk menghilangkan pertukaran. Komodifikasi adalah dahaga, cerita untuk berkomunikasi proses perubahan nilai guna menjadi atau berbagi pengalaman), menjadi nilai tukar.

komoditas yang bernilai karena ia Para ahli teori komodifikasi bisa mendatangkan keuntungan di budaya berpendapat bahwa strategi pasar setelah dikemas menjadi industry budaya terutama sukses di minuman dalam botol dan buku Amerika Serikat, karena para novel, ataupun misalnya, entrepreneur media relatif tetap komersialisasi pertanian untuk independen dari lembaga-lembaga menjual makanan dan produksi politik. Budaya massa meraih drama untuk penyiaran komersial. popularitas terus-menerus, Adam Smith dan penganjur ekonomi menelurkan industri-industri besar politik klasik telah membedakan yang sukses berkompetisi untuk 
merebut perhatian dan minat atau imperialisme media dan budaya

kebanyakan orang Amerika. yang juga telah menimbulkan

Mungkin itulah sebabnya, perdebatan di kalangan pengkaji

dibandingkan dengan apa yang budaya dan media (Ibrahim dan

terjadi di Eropa, kritik terhadap Akhmad, 2014:26-27).

budaya massa di Amerika Serikat

Dalam perkembangan

cenderung membisu. Kebanyakan kemudian, pandangan pendukung

orang Amerika menerima komoditas imperialisme budaya telah dikritik,

budaya yang muncul dari New York misalnya, oleh pandangan yang lebih

dan Hollywood entah bagaimana pun cenderung melihat bahwa globalisasi

sebagai milik mereka. Tetapi, juga menciptakan adaptasi dan

komoditas komoditas budaya yang akomodasi budaya lewat proses

sama ini telah memunculkan "globalisasi", yang gilirannya

kontroversi yang luar biasa ketika melahirkan corak budaya yang

para entrepreneur media AS disebut oleh Garcia Caclini sebagai

mengekspornya ke negara lain. "budaya hibrida" (hybrid cultures),

Kekuatan komoditas ini untuk atau sebagai logika budaya

membentuk kembali kehidupan globalisasi yang disebut oleh $\mathrm{M}$.

sehari-hari lebih jelas di kebanyakan Kraidy sebagai "hibriditas"

negara Dunia Ketiga, dan bahkan (hybridity), atau kami menyebutnya

dianggap lebih berbahaya dan "budaya glokal", karena globalisasi

merusak. Inilah yang kemudian itu sendiri adalah proses 'hibridasi',

melahirkan isu-isu seperti sebagaimana juga ditegaskan oleh

Amerikanisasi, kolonialisasi baru, Nederveen Pieterse. 
Metode Penelitian

Jenis penelitian yang

digunakan adalah metode deskriptif

dengan pendekatan kualitatif.

Menurut Hikmat (2011:37-38)

metode kualitatif sebagai prosedur

penelitian yang menghasilkan data

deskriptif berupa kata-kata tertulis

atau lisan dari orang-orang dan

berperilaku yang dapat diamati.

Metode kualitatif dipergunakan

dengan bebrapa pertimbangan:

Pertama, menyesuaikan metode

kualitatif lebih mudah apabila

berhadapan dengan kenyataan ganda.

Kedua, metode ini menyajikan

secara langsung hakikat hubungan

antara peneliti dengan responden.

Ketiga, metode ini lebih peka dan

lebih dapat menyesuaikan diri

dengan banyak penajaman pengaruh

bersama dan terhadap pola-pola nilai

yang dihadapi.

Dalam penelitian ini, menggunakan beberapa teknik

pengumpulan data, yaitu:

Wawancara, observasi dan

dokumentasi. Objek penelitian ini adalah anggota dari komunitas anime

One Piece di Kota Medan. Mereka adalah komunitas yang terbentuk karena dasar kesukaan mereka dengan anime One Piece tersebut. Komunitas ini dibentuk pada bulan Juni 2016 yang di awali oleh beberapa orang yang bertemu di sosial media sehingga timbul ide untuk membentuk sebuah komunitas anime.

\section{Hasil Penelitian dan Pembahasan}

Hasil penelitian menunjukkan bahwa perilaku anggota komunitas One Piece ID Medan dalam menyebarkan budaya yang timbul dari anime One Piece dengan sesama penggemar sangat baik sehingga membuat proses komodifikasi yang 
terjadi dengan budaya anime One

Piece ini sangat terasa. Dari segi

budaya banyak anggota komunitas

tersebut yang mengadaptasi fashion

yang ada dari anime One Piece

tersebut. Kemudian, ada anggota

komunitas yang memakai baju

bertema anime tersebut, selain itu

ada juga anggota komunitas tersebut

yang memakai pernak pernik dari

anime tersebut, ada yang berupa

gantungan kunci maupun setelan

jaket yang bergambar lambang dari

bajak laut Mugiwara Luffy yang

menjadi aktor utama dalam cerita

anime One Piece tersebut.

Selain itu kegiatan yang

dilakukan anggota komunitas

tersebut dalam hal mengikuti event-

event yang berkaitan dengan anime

One Piece tersebut, mereka juga

terkadang melakukan kegiatan

positif lain berupa bakti sosial,

seperti bakti sosial mengumpulkan sumbangan untuk korban bencana, contohnya kemarin ada bencana alam berupa gempa bumi yang terjadi di Palu, Sigi dan Donggala dan mereka melakukan kegiatan bakti sosial tersebut.

Kemudian para anggota yang tergabung dengan komunitas tersebut, mereka lebih merasa kreativitas yang mereka miliki sangat terdukung dibalik adanya komunitas tersebut, dengan cara adanya salah satu anggota komunitas yang berkreasi dengan mengolah limbah bekas yang ia buat menjadi sebuah souvenir yang bertema anime One Piece tersebut. Selain itu ada juga anggota komunitas yang suka menggambar sketsa, ia memanfaatkan bakatnya itu dengan menggambar sketsa tokoh anime tersebut sehingga kemudian ia jual dan menjadikannya sebagai komoditi yang menguntungkan bagi dirinya 
maupun bagi komunitasnya.

Komunitas yang merupakan

wadah pemersatu penggemar anime

One Piece tersebut juga melakukan

hal-hal lain diantaranya adalah menyebarkan budaya Jepang serta juga manjadi wadah pembelajaran bahasa Jepang diantara penggemar anime One Piece tersebut. Mereka sangat membantu dalam hal penyebaran tren budaya yang timbul

di kalangan penggemar anime, mereka menyebarkan berbagai hal tersebut dengan dibantu oleh perkembangan teknologi yang sangat cepat di jaman ini.

Komunitas tersebut juga selalu mengikuti event-event seperti event cosplay serta event kompetisi menggambar sketsa dari tokoh anime yang ada di dalam cerita anime One Piece tersebut. Dengan mereka mengikuti acara seperti itu keuntungan lain yang mereka dapat seperti mereka lebih dikenal oleh masyarakat dengan adanya komunitas yang mereka dirikan.

Selain itu kegiatan yang dilakukan anggota komunitas tersebut dalam hal mengikuti eventevent yang berkaitan dengan anime One Piece tersebut, mereka juga terkadang melakukan kegiatan positif lain berupa bakti sosial, seperti bakti sosial mengumpulkan sumbangan untuk korban bencana.

Sebagai komunitas yang berorientasi membahas segala hal berkaitan dengan anime One Piece tersebut. Mereka sering melakukan pembahasan megenai anime tersebut terkait dengan membahas bagaimana cerita anime tersebut berlangsung maupun juga membahas bagaimana karakter-karakter yang ada di dalam anime tersebut, selain itu juga mereka terus memperkenalkan diri di masyarakat bahwasanya komunitas 
anime tersebut bukan hanya sekedar membahas anime melainkan juga sebagai pemersatu antar penggemar anime One Piece dan juga sebagai wadah positif antar penggemar meluangkan pemikirannya.

Komunitas yang merupakan wadah pemersatu penggemar anime One Piece tersebut juga melakukan hal-hal lain diantaranya adalah menyebarkan budaya Jepang serta juga manjadi wadah pembelajaran bahasa Jepang diantara penggemar anime One Piece tersebut. Mereka sangat membantu dalam hal penyebaran tren budaya yang timbul di kalangan penggemar anime, mereka menyebarkan berbagai hal tersebut dengan dibantu oleh perkembangan teknologi yang sangat cepat di jaman ini.

Selain itu di era milenial ini para peminat juga sudah mudah mendapatkan informasi terkait dengan anime One Piece tersebut, ada diantaranya dengan banyak tersebar website ataupun blog yang membahas atau hanya sekedar sebagai wadah bagi penggemar anime untuk mudah mengakses berbagai tayangan dan bacaan dari anime dan manga. Sehingga membuat para penggemar semakin tertarik dengan adanya anime tersebut. Sebagai anggota komunitas One Piece ID Medan penulis mendapatkan beberapa hal yang menjadi faktor pendukung mudahnya penyebaran maupun komodifikasi yang terjadi terhadap budaya populer anime One Piece tersebut.

Tren budaya yang timbul akibat adanya anime One Piece tersebut membuat semakin mudah penyebaran budaya anime One Piece tersebut sehingga banyak publik yang menyukai anime serta juga banyak yang mengikuti tren fashion 
maupun tren lain yang timbul dari adanya anime tersebut. Sebagai anggota komunitas anime One Piece tersebut mereka banyak yang memakai pernak pernik yang berkaitan dengan anime tersebut, sehingga publik melihat dan menilai serta juga menjadi tahu bahwa yang mereka pakai adalah bagian dari tren budaya yang timbul karena adanya anime One Piece tersebut.

Mereka juga menyebarkan tren budaya yang timbul dari anime tersebut sebagai hobby yang mereka sukai tanpa adanya norma yang dilanggar dimasyarakat sehingga masyarakat menyambut baik dengan adanya komunitas tersebut, masyarakat melihat komunitas tersebut sebagai wadah positif yang ada di masyarakat. Dengan adanya kegiatan positif yang dilakukan oleh komunitas tersebut.

Kemudian terdapat hal menarik terkait dengan komodifikasi budaya yang ada di dalam anime One Piece di masyarakat, contohnya Ganda yang mengatakan bahwa tren budaya yang ada di masyarakat sangat cepat berkembang dengan adanya orang-orang yang mengikuti tren fashion yang diangkat dari anime tersebut serta dia juga mengatakan bahwa jaman sekarang ini publik lumayan menyukai anime tersebut walaupun tidak semua kalangan yang mudah mengerti dengan alur cerita anime One Piece tersebut.

Keunikan serta originalitas dari anime One Piece membuat para penggemar semakin mengimitasi budaya yang ada serta semakin tertarik dengan mengoleksi berbagai hal terkait dengan anime One Piece tersebut. Contohnya saja seperti semakin banyaknya penggemar memakai aksesoris yang bertema 
anime One Piece tersebut. Ada juga yang mengadaptasi tren fashion yang diangkat dari gaya berpakaian maupun gaya rambut yang ada pada karakter-karakter anime One Piece tersebut.

\section{Penutup}

Tren budaya yang ditimbulkan oleh adanya anime One Piece tersebut membuat masyarakat yang mengikuti tren fashion yang diangkat dari tokoh atau karakter yang ada dalam anime One Piece tersebut. Tingkat kesukaan publik terhadap anime One Piece tersebut sangat meningkat dikarenakan mudahnya akses untuk mendapatkan berbagai informasi terkait dengan tren budaya sehingga meningkatkan minat penggemar dalam hal mempelajari maupun mengadaptasi tren tersebut.

Anime One Piece sangat mudah diadaptasi oleh penggemar karena banyak penggemar yang mengikuti dan meniru berbagai hal contohnya seperti semakin banyak gaya berpakaian atau cosplay yang digunakan oleh penggemar.

Banyak keuntungan yang diperoleh dari adanya anime One Piece tersebut contohnya dari adanya penjualan merchandise serta aksesoris dan pakaian yang bertema anime One Piece tersebut dan ada juga keuntungan lain seperti semakin banyaknya kontes maupun eventevent yang dilakukan bertema tentang anime.

Sisi negatif yang timbul dari adanya anime One Piece dari psikologis adalah dengan adanya candu dengan tayangan anime tersebut membuat para peminat atau penonton kurang produktif dalam beraktifitas dengan timbulnya sifat tak acuh dengan lingkungan atau tidak peduli dengan lingkungan 
sekitar.

Akibat yang ditimbulkan juga semakin tergerusnya budaya lokal yang ada di Indonesia dengan adanya budaya Jepang yang masuk melalui tayangan anime One Piece tersebut dengan banyak budaya Jepang yang ditiru atau di imitasi oleh peminat atau penonton tayangan anime tersebut.

\section{Daftar Pustaka}

Bungin, Burhan. 2006. Sosiologi Komunikasi: Teori, Paradigma dan Diskursus Teknologi Komunikasi di Masyarakat. Jakarta: Kencana Prenada Media Group

Hikmat, Mahi M. 2011. Metode Penelitian Dalam Perspektif Ilmu Komunikasi dan Sastra. Yogyakarta: Graha Ilmu.

Heryanto, Ariel. 2012. Budaya Populer di Indonesia Mencairnya Identitas PascaOrde Baru. Yogyakarta: Jalasutra.

Ibrahim, Idi Subandy, Bachruddin Ali Akhmad. 2014. Komunikasi dan Komodifikasi: Mengkaji Media dan Budaya dalam Dinamika Globalisasi. Jakarta: Yayasan Pustaka Obor Indonesia.
Rahayu, Ani Sri. 2016. ISBD Perspektif Baru Membangun Kesadaran Global Melalui Revolusi Mental. Jakarta: Bumi Aksara.

Subiakto, Henry dan Rachmah Ida. 2012. Komunikasi Politik, Media, dan Demokrasi. Jakarta: Kencana Prenada Media Group. 